\section{Wind-blown, flash flood-deposited sands of Hagari River, Anantapur district, Andhra Pradesh, India}

\author{
Vishwas S. Kale $^{1, *}$, A. C. Narayana ${ }^{2}$ and \\ Manoj K. Jaiswal ${ }^{3}$ \\ ${ }^{1}$ Formerly at the Department of Geography, SP Pune University, \\ Pune 411007 , India \\ ${ }^{2}$ Centre for Earth, Ocean and Atmospheric Sciences, \\ University of Hyderabad, Hyderabad 500 046, India \\ ${ }^{3}$ Department of Earth Sciences, Indian Institute of Science Education \\ and Research, Kolkata 741246 , India
}

Sand sheets and mounds occur along the eastern bank of Hagari River in Anantapur district, Andhra Pradesh, India. These wind-blown sands are considered to be deposited by a flood about 1-2 centuries ago. Based on the description in the British era District Gazetteer, we infer that the sands were most likely deposited by a flash flood in May 1851.

Keywords: Aeolian sands, buried temples, desertification, flash floods, flood deposits.

THICK accumulations of yellowish-brown sands occur in the form of sand sheets and dune-like sand mounds along a roughly $50 \mathrm{~km}$ stretch on the eastern bank of the Hagari River in Anantapur district, Andhra Pradesh and Bellary district, India ${ }^{1}$ (Figures 1 and 2). In this stretch, the shallow channel of the Hagari occupies a relatively wide valley with low relief. With a catchment area of $\sim 23,590 \mathrm{~km}^{2}$, the Hagari or Vedavathi is the southern tributary of River Tungabhadra. The river rises in the Bababudan Hills and flows eastward from the central part of the western Dharwar craton cutting across the NW-SE trending geological units of Chitradurga schist belt and the Peninsular gneiss and granitoids ${ }^{2}$. After crossing the Chitradurga thrust zone, the river turns towards northeast in the region exposing the Closepet Granites, migmatites and younger granitoids ${ }^{2}$. Further downstream, the Hagari flows northwards over Peninsular gneissic complex and finally joins the River Tungabhadra. Part of its course is in the rain-shadow zone of southern India.

The sediments, dominated by moderately well-sorted, medium $(\sim 61-67 \%)$ to fine $(\sim 30 \%)$ sands, are spread over an area of $\sim 3400$ ha on the right (eastern) bank of Hagari River $^{1}$. Due to the cohesionless nature of the Hagari sands, during hot summers when the moisture content is low, strong winds are able to easily move the sands to form sheets and mounds.

Although a study based on remote sensing had inferred a decline in the area covered by aeolian (wind-blown) sands between 1973 and 2015 (ref. 3), recent reports and observations indicate that the shifting sands are seriously

*For correspondence. (e-mail: vskale.unipune@gmail.com) affecting agricultural productivity and livelihood of villages on the eastern bank of the Hagari ${ }^{4,5}$. The recurring problem of wind-blown sands burying cropped lands and cultivable areas in recent decades has also been attributed to the prolonged periods of dry Hagari channel. After the construction of the Bhairavanithippa Dam upstream in 1961, monsoon flow into the river has substantially declined $^{4}$. Uncontrolled exploitation of groundwater is another reason for significant decline in the groundwater level and consequently in the river base-flow. Decreasing trend in monsoon rainfall is further aggravating the problem. Trend analyses of rainfall data (1981-2016) for stations in Anantapur district indicate a decreasing trend during the southwest monsoon rainfall for most stations (including Kanekallu; Figure 3) and significant decrease in the monsoon rainfall at Uravakonda ${ }^{6}$ (see Figure 3 for location), which are close to the sand-covered areas.

These wind-blown riverine sands are considered to be deposited during a large flood about 1-2 centuries ago ${ }^{4}$. The Anantapur District Gazetteer published in 1970 mentions that the Sri Ranganatha Temple located at Vepalaparthi $\left(14^{\circ} 34^{\prime} 9^{\prime \prime} \mathrm{N}, 76^{\circ} 53^{\prime} 3^{\prime \prime} \mathrm{E}\right)$ on the right bank of the Hagari in Kalyandurge Taluk, had been completely buried under wind-blown sands till 1930, when it was excavated and restored ${ }^{7}$. This logically implies that the extraordinary flood event occurred sometimes before
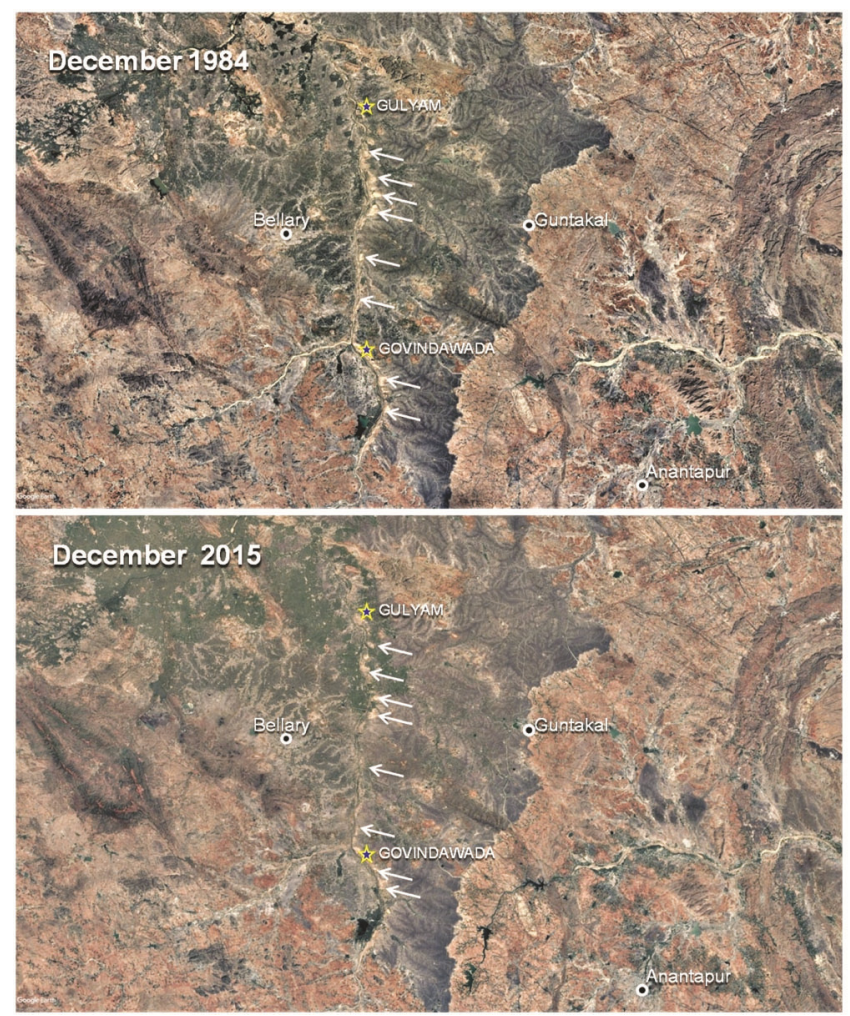

Figure 1. Google Earth images showing prominent locations (arrows) of sand exposures (light coloured) on the right bank of River Hagari in December 1984 and December 2015. Image base for both images is about $175 \mathrm{~km}$. 


\section{RESEARCH COMMUNICATIONS}
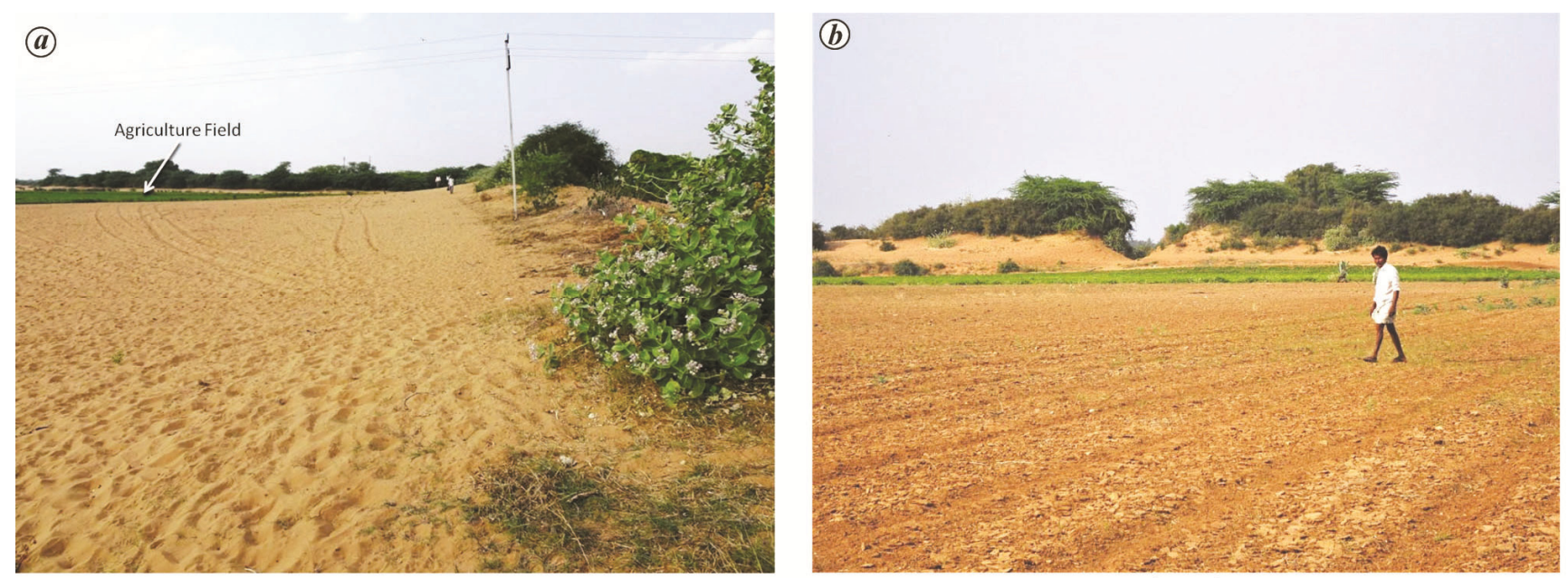

Figure 2. Photographs showing wind-blown sand deposits between Govindavada and Honnuru villages (see Figure 3 for location). a, Aeolian sand-covered area along Hagari River. Arrow indicates cropped area on the sand sheet. $\boldsymbol{b}$, The well-vegetated sand ridge in the background and ploughed field in the foreground close to the Hagari right bank. Two luminescence ages of sands from the base of the man-made ridge indicate that the sediments are about a hundred years old.

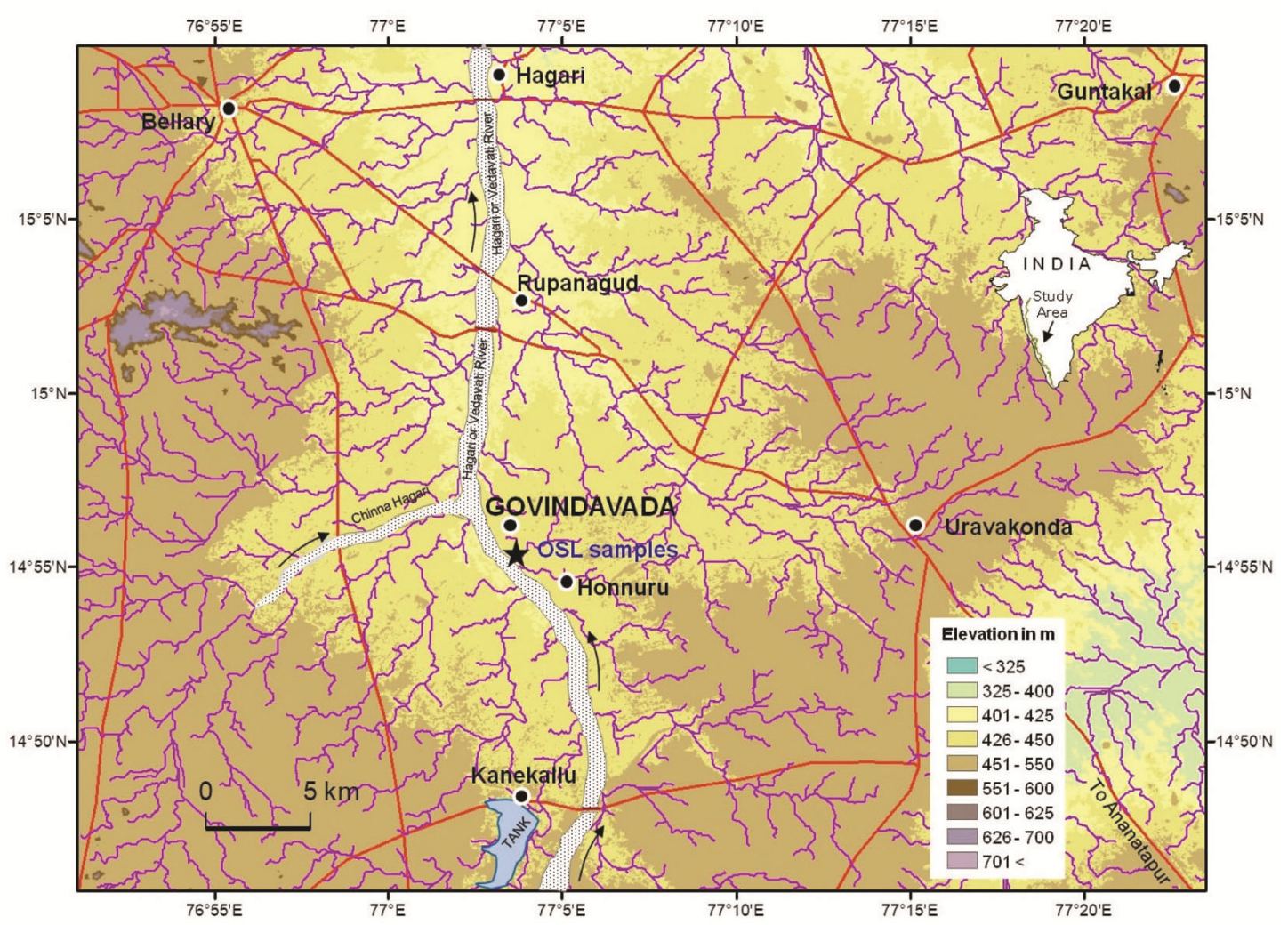

Figure 3. Map of the study area showing the locations of Govindavada, Honnuru and other places mentioned in the text.

1930. The Gazetteer also provides information about damages by major floods in 1804, 1817, 1851 and 1874 (ref. 7), but does not mention about widespread sand deposition by a large flood before 1930 .

We, therefore, decided to look for information in the older gazetteers of the British era, namely the Imperial Gazetteer of India and the Madras District Gazetteers.
The first volume of the Madras District Gazetteers was on Bellary district and was published in 1904 (ref. 8). This Gazetteer includes material from the original $\mathrm{Ma}$ nual of Bellary written in 1872 (ref. 8). Interestingly, this Gazetteer mentions about a 'Great Storm of 5th May 1851' in Bellary and Anantapur during which 'Channels were swept away or obliterated, much land was ruined by 


\section{RESEARCH COMMUNICATIONS}

the sand which was deposited on it... ${ }^{8}$. The Gazetteer also mentions that during this three-day disastrous storm, the old headquarter town of Guliam (Gulyam, Figure 1) located on the right bank of the Hagari 'was swept away and many lives were lost ${ }^{, 8,9}$.

Three main inferences can be drawn from the above description: (a) since the 1851 flood was storm-induced, and occurred in early May (and not during the monsoon months), it was most likely a severe flash flood; (b) due to the flashy nature of the flood, large quantities of sand were transported and deposited during this event, and (c) the flash flood was concentrated on the right bank of Hagari River. As the river in this entire stretch displays low sinuosity (Figure 1), the only explanation for the concentration of floodwaters on the right bank is that its elevation was relatively lower than the left bank.

As no comparable flood occurred on the Hagari until the beginning of the 20th century, that is, before the publication of the 1904 Gazetteer on Bellary district, it is reasonable to conclude that the bulk of the wind-blown sands was likely initially deposited by the Hagari on the right bank by an extreme flash-flood during the Great Storm of May 1851, that is about 170 years ago. Preliminary optically stimulated luminescence (OSL) dates of the dune sand grains obtained from the base of a sand ridge near Govindavada (Figures $2 b$ and 3 ) yielded ages between 100 and 110 years, suggesting that the sands were deposited by the river before the 20th century. There is a need to further confirm this by taking deep cores at multiple locations in the sand-covered areas and obtaining reasonable number of OSL ages.

The highest monsoon flood on the Hagari during the last 50 years was recorded in October 2009 (Figure 4). There are no reports of large-scale sand deposition during this event. To some extent, this may be due to the trapping of sediments behind the Bhairavanithippa Dam.

Wind-blown sandy deposits in the form of sheets and dunes on river banks, although rare, are not completely

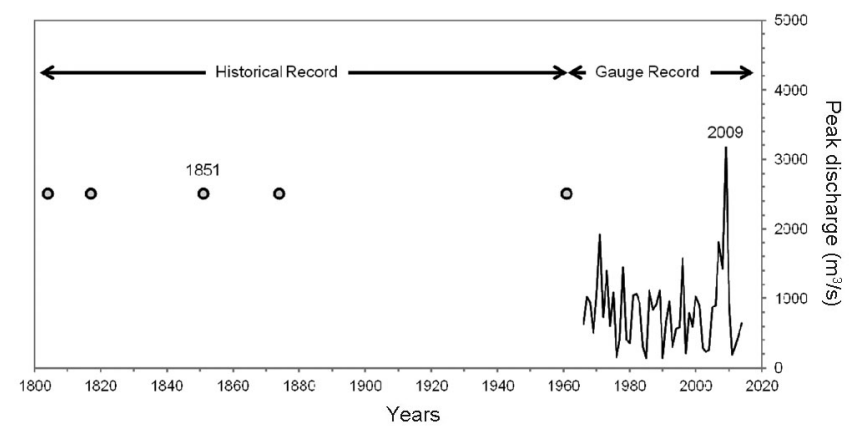

Figure 4. Time-series plot of the annual peak discharge from 1966 to 2015 at T-Ramapuram gauging site $\left(15^{\circ} 39^{\prime} 43^{\prime \prime} \mathrm{N}, 7^{\circ} 57^{\prime} 55^{\prime \prime} \mathrm{E}\right)$ on Hagari River and major historical floods in the area during the pregauging period (hollow circles). In the absence of information about the magnitude of the pre-1966 floods, historical events are just plotted in a straight line. (Source of annual peak discharge data: Central Water Commission, Hyderabad.) unheard of. Talkad town on the left bank of River Kaveri, Karnataka, is well-known for its old temples buried under large sand dunes ${ }^{10}$. Similarly, old temples at Pamidi, Andhra Pradesh, buried under sand dunes from River Penneru are mentioned in the Anantapur District Gazetteer $^{7}$. Typical aeolian sand dunes are also present near Prakasha, Gujarat, on the left bank of River Tapi ${ }^{11}$. However, the wind-blown sands of the Hagari are of greater scientific, touristic and environmental value because: (a) huge amounts of sand were deposited by the Hagari over a large area most likely by a storm-induced flash flood of 1851 in the dry season, and (b) the wind-mobilized sands still cover a large area (>3000 ha) and approximately a $50 \mathrm{~km}$ long stretch of the Hagari, causing desertification due to sand encroachment.

1. NBSS\&LUP, Soils of Bellary district, National Bureau of Soil Survey and Land Use Planning, Nagpur, Report No. 357, 2008.

2. Ramakrishnan, M. and Vaidyanadhan, R., Geology of India, Vol. 1, Geological Society of India, Bangalore, 2008.

3. Kar, A., Ajai and Dwivedi, R. S., Desertification. In Geospatial Technology: For Integrated Natural Resources Management (eds Dwivedi, R. S. and Roy, P. S.), Yes Dee Publishing, Chennai, 2016, pp. 295-320.

4. Jena, M., Creeping Deserts and Crouching Hunger, Inter Press Service News Agency, 2010; http://www.ipsnews.net/2010/ 01/environment-india-creeping-deserts-and-crouchinghunger/

5. Kumar, B. P., Babu, K. R., Ramachandra, M., Krupavathi, C., Swamy, B. N., Sreenivasulu, Y. and Rajasekhar, M., Data on identification of desertified regions in Anantapur district, southern India by NDVI approach using remote sensing and GIS. Data Brief, 2020, 30, 105560; https://doi.org/10.1016/j.dib.2020.105560

6. Patakamuri, S. K., Muthiah, K. and Sridhar, V., Long-term homogeneity, trend, and change-point analysis of rainfall in the arid district of Ananthapuramu, Andhra Pradesh State, India. Water, 2020, 12, doi:10.3390/w12010211

7. Sivasankaranarayana, B. H., Anantapur. Andhra Pradesh District Gazetteers, Director of Printing and Stationery, The Government Secretariat PRBBS, Hyderabad, 1970.

8. Francis, W., Madras District Gazetteers: Bellary, Government Press, Madras, 1904.

9. Abhishankar, K., Bellary District Gazetteer, Karnataka Government, Bangalore, 1972.

10. Srikantia, S. V. and Anantharamu, T. R., The Talkad sand dunes in Mysore district of Karnataka - their description, evolution and origin. J. Geol. Soc. India, 1997, 50, 315-321.

11. Kale, V. S. (ed.), Atlas of Geomorphosites in India, Indian Institute of Geomorphologists, Allahabad, 2017, p. 132.

ACKNOWLEDGEMENTS. A.C.N. thanks the Ministry of Earth Sciences, Government of India for funds through a research project (No. MoES/16/02/2012-RDEAS) to undertake field work. We thank the reviewers for helpful and constructive suggestions.

Received 29 January 2020; revised accepted 2 June 2020

doi: $10.18520 / \mathrm{cs} / \mathrm{v} 119 / \mathrm{i} 3 / 556-558$ 